\title{
Innovation in B.Tech. Curriculum as B.Tech. (Hons) by integrating STEAM, ESEP \& IPR features
}

\author{
P. S. Aithal ${ }^{1}$, \& Shubhrajyotsna Aithal $^{2}$ \\ ${ }^{1}$ College of Management \& Commerce, Srinivas University, Mangalore, India. \\ ${ }^{2}$ Faculty, College of Engineering \& Technology, Srinivas University, Mangalore, India \\ E-mail: psaithal@gmail.com
}

Type of the Paper: Explorative Research.

Type of Review: Peer Reviewed.

Indexed In: OpenAIRE.

DOI: http://doi.org/10.5281/zenodo.3248630.

Google Scholar Citation: IJCSBE

\section{How to Cite this Paper:}

Aithal, P. S., \& Aithal, Shubhrajyotsna. (2019). Innovation in B.Tech. Curriculum as B.Tech. (Hons) by integrating STEAM, ESEP \& IPR features. International Journal of Case Studies in Business, IT, and Education (IJCSBE), 3(1), 56-71.

DOI: http://doi.org/10.5281/zenodo.3248630.

International Journal of Case Studies in Business, IT and Education (IJCSBE) A Refereed International Journal of Srinivas University, India. IFSIJ Journal Impact Factor for 2019-20 = 4.252

(C) With Authors.

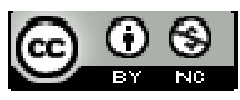

This work is licensed under a Creative Commons Attribution-Non Commercial 4.0 International License subject to proper citation to the publication source of the work.

Disclaimer: The scholarly papers as reviewed and published by the Srinivas Publications (S.P.), India are the views and opinions of their respective authors and are not the views or opinions of the S.P. The S.P. disclaims of any harm or loss caused due to the published content to any party. 


\title{
Innovation in B.Tech. Curriculum as B.Tech. (Hons) by integrating STEAM, ESEP \& IPR features
}

\author{
P. S. Aithal ${ }^{1}$, \& Shubhrajyotsna Aithal $^{2}$ \\ ${ }^{1}$ College of Management \& Commerce, Srinivas University, Mangalore, India. \\ ${ }^{2}$ Faculty, College of Engineering \& Technology, Srinivas University, Mangalore, India \\ E-mail: psaithal@gmail.com
}

\begin{abstract}
Innovation in course curriculum is a continuous process in the higher education system (HES). As the amount of published information growing with time at geometric progression, it is necessary to increase the depth and breadth of the HES curriculum of every course with time. Engineering education is one of the prominent areas in science \& technology education, finding many opportunities and facing many challenges in the $21^{\text {st }}$ century due to the accelerated advancement of technologies in many areas. Keeping students in pace with such developments and adopting such newly emerging areas of technology in the current curriculum is an essential requirement of the education industry's progress. In this paper, we have proposed improvement in engineering education in India at the undergraduate level by means of six innovations to improve the depth, breadth, and vigorousness of the B.Tech. programme by suggesting a Student integrated development Framework in engineering based on STEAM-Employability Model with a focus on experimental learning. The six innovations proposed in this model upgrades the B.Tech. (Pass) programme into B.Tech. (Honours). The advantages, benefits, constraints, and disadvantages from students, institutions, and job offering industries point of view are analysed to check this model of B.Tech. (Honours) for its effectiveness in its objective of enhancing competency and employability of graduates to secure better employment.
\end{abstract}

Keywords: B.Tech. degree, B.Tech. (Hons), Engineering curriculum, STEM, STEAM, Employability skill enhancement program (ESEP), Experimental learning, STEAMEmployability Model.

\section{INTRODUCTION :}

Higher education system (HES) has an objective of improving the knowledge, skills, experience, \& ethics of students towards increasing their confidence to identifying and solving problems of the society through effective and contemporary education using a suitable teaching-learning model [1]. Innovation in course curriculum is a continuous feature in the higher education system. As the amount of published information growing with time at geometric progression, it is necessary to increase the depth and breadth of the HES curriculum of every course with time. This also involves in removing obsolete part of the curriculum without hesitation to give room for new and emerging issues in the course subjects. Upgrading HE curriculum by adding area based specific focus models like STEM (Science, Technology, Engineering, and Mathematics), and STEAM (Science, Technology, Engineering, Arts \& design, and Mathematics) are the current trend in both secondary and college education system. It is believed that such an education model can prepare students allrounder to face any challenges in their life and make them innovative in their working place. Apart from area-based specific focus during higher education which enhances knowledge and subjectspecific skills, additional supporting skills like communication, proficiency in writing, generation of new ideas, enhancing competitiveness, preserving a vision in life, desire for learning and improvement in life, attitude towards life, respect for fellow-beings, self-control and such other qualities inculcate confidence and enhances leadership behaviour among the students to become 
winner in competitive society. These factors also enhance the employability of the students in industry specific areas where general skills and competency are essential for survival [2].

Engineering education is one of the prominent areas in science \& technology education, finding many opportunities and facing many challenges in the $21^{\text {st }}$ century due to the accelerated advancement of technologies in many areas of society [3-5]. Technology is considered as lifeblood of all developments and solutions to all problems related to basic needs, advanced wants, and dreamy desires of human being in the society. Keeping engineering students in pace with such developments and adopting such newly emerging areas of technology in the current curriculum is an essential requirement of the education industry's progress. In this paper, we have proposed a new improved model on engineering education system of India which includes basically STEAM model with employment skills enhancement program (ESEP) subjects in every semester and earning IPR by every student as top-ups. This model proposes six innovations at the undergraduate engineering level to improve the depth, breadth, and vigorousness of the B.Tech. programme by suggesting a Student focussed integrated development (SFID) Framework. This integrated development framework in engineering education is based on STEAM-Employability Model with a focus on experimental learning. The six innovations proposed in this model with increased credits in every semester upgrades the conventional B.Tech. (Pass) programme into B.Tech. (Honours). The advantages, benefits, constraints, and disadvantages from students, institutions, and job offering industries point of view are analysed. Many recommendations are submitted based on the analysis to make this model of B.Tech. (Honours) more effective in its objective of enhancing competency, confidence, and employability of graduates to secure better job.

\section{RELATED SCHOLARLY WORKS :}

\subsection{STEM Model as First School of Innovative Thought :}

STEM (Science, Technology, Engineering, and Mathematics) as integrated single subject in school education is becoming popular in many countries and now spreading its roots to higher education system. Apart from school education, if college level curriculum is planned with STEM subjects, the scientific thinking and innovative ability of students can be improved to make them smart graduates who can adopt technology in decision making and problem solving. In STEM curriculum model at college level, a student has to study science, technology, engineering, and mathematics subjects in each year (preferable in semester) to be competitive in order to get further opportunities. Identifying such subjects in a systematic combination to make effective STEM interconnected model is the challenge for educators. Table 1 contains some of research papers published during the $21^{\text {st }}$ century related to college education.

Table 1 : Published papers related to STEM education

\begin{tabular}{|c|c|c|c|}
\hline S. No. & STEM Curriculum & Focus & Reference \\
\hline 1 & $\begin{array}{l}\text { 21st century STEM education } \\
\text { concepts \& priorities }\end{array}$ & $\begin{array}{l}\text { A tactical model for } \\
\text { long-range success }\end{array}$ & Ostler, E. (2012). [6] \\
\hline 2 & STEM subjects for College education & $\begin{array}{l}\text { College student } \\
\text { pathways to the STEM } \\
\text { disciplines }\end{array}$ & $\begin{array}{l}\text { Engberg, M., (2013) } \\
\text { [7] }\end{array}$ \\
\hline 3 & $\begin{array}{l}\text { Facilitating change in undergraduate } \\
\text { STEM education }\end{array}$ & $\begin{array}{l}\text { STEM for Change in } \\
\text { knowledge \& skills }\end{array}$ & $\begin{array}{l}\text { Beach, A. L., (2012) } \\
{[8]}\end{array}$ \\
\hline 4 & $\begin{array}{l}\text { Innovation processes in university } \\
\text { STEM education }\end{array}$ & System model & $\begin{array}{l}\text { Porter, A. L., (2016) } \\
\text { [9] }\end{array}$ \\
\hline 5 & Integrated STEM education & $\begin{array}{l}\text { Benefits and procedure } \\
\text { of integration }\end{array}$ & $\begin{array}{l}\text { Roehrig, G. H., (2015) } \\
\text { [10] }\end{array}$ \\
\hline 6 & How an integrative STEM curriculum & $\begin{array}{l}\text { For students of } \\
\text { engineering design } \\
\text { practices }\end{array}$ & Fan, S. C., (2017) [11] \\
\hline 7 & $\begin{array}{l}\text { From STEM to STEAM Strategies for } \\
\text { enhancing engineering \& technology } \\
\text { education }\end{array}$ & $\begin{array}{l}\text { Importance of Arts \& } \\
\text { Design education for } \\
\text { enhancing creative } \\
\text { abilities }\end{array}$ & $\begin{array}{l}\text { Connor, A., et al. } \\
\text { (2015) [12] }\end{array}$ \\
\hline
\end{tabular}

P. S. Aithal et al, (2019); www.srinivaspublication.com 


\begin{tabular}{|l|l|l|l|}
\hline 8 & The potential of technology education & STEM education & $\begin{array}{l}\text { Wells, J. G. (2008) } \\
{[13]}\end{array}$ \\
\hline 9 & STEM and technology education & $\begin{array}{l}\text { International state-of- } \\
\text { the-art education }\end{array}$ & Ritz, J. M., (2015) [14] \\
\hline 10 & $\begin{array}{l}\text { Developing effective STEM } \\
\text { professional development programs }\end{array}$ & $\begin{array}{l}\text { Design of STEM } \\
\text { programs }\end{array}$ & $\begin{array}{l}\text { Avery, Z. K., (2013) } \\
{[15]}\end{array}$ \\
\hline 11 & $\begin{array}{l}\text { Reformation of engineering } \\
\text { education. }\end{array}$ & $\begin{array}{l}\text { Transitioning from } \\
\text { STEM to STEAM }\end{array}$ & $\begin{array}{l}\text { Watson, A. D., } \\
\text { (2013) [16] }\end{array}$ \\
\hline 12 & Rethinking STEM education & $\begin{array}{l}\text { An interdisciplinary } \\
\text { STEAM curriculum }\end{array}$ & Madden, M. E., [17] \\
\hline
\end{tabular}

\subsection{STEAM Model as Second School of Innovative Thought :}

An improvement in STEM is argued by many researchers in education to make students as allrounders. As per this argument, apart from learning for knowledge, skills, and experience which are specific for a given industry, student should also enhance their creative thinking and design abilities by involving in art and design related trainings. Hence a new model which integrates STEM with Arts \& Design subjects is proposed. Based on studies it is realized that such a transdisciplinary STEAM model is the current requirement to enhance the creative thinking abilities among engineering graduates. Table 2 reviews some of the papers published related to STEAM education model.

Table 2 : Published papers related to STEAM education

\begin{tabular}{|c|c|c|c|}
\hline S. No. & STEAM Curriculum & Focus & Reference \\
\hline 1 & STEAM education & $\begin{array}{l}\text { Development of a theoretical } \\
\text { model }\end{array}$ & $\begin{array}{l}\text { Kim, Sung-Won, et } \\
\text { al. (2012) [18] }\end{array}$ \\
\hline 2 & $\begin{array}{l}\text { Development and application of } \\
\text { STEAM teaching model }\end{array}$ & $\begin{array}{l}\text { Based on the Rube } \\
\text { Goldberg's invention }\end{array}$ & $\begin{array}{l}\text { Kim, Y., (2012) [19 } \\
\text { 2] }\end{array}$ \\
\hline 3 & $\begin{array}{l}\text { A study of teaching-learning } \\
\text { methods for the IT-based } \\
\text { STEAM education model }\end{array}$ & $\begin{array}{l}\text { With regards to developing } \\
\text { people of interdisciplinary } \\
\text { abilities }\end{array}$ & $\begin{array}{l}\text { Kim, J. A., (2011) } \\
\text { [20] }\end{array}$ \\
\hline 4 & Rethinking STEM education & $\begin{array}{l}\text { An interdisciplinary } \\
\text { STEAM curriculum }\end{array}$ & $\begin{array}{l}\text { Madden, M. E., } \\
(2013)[21]\end{array}$ \\
\hline 5 & Transitioning STEM to STEAM & $\begin{array}{l}\text { Reformation of engineering } \\
\text { education }\end{array}$ & $\begin{array}{l}\text { Watson, A. D., } \\
(2013)[22]\end{array}$ \\
\hline 6 & From STEM to STEAM & $\begin{array}{l}\text { Toward a human-centred } \\
\text { education }\end{array}$ & $\begin{array}{l}\text { Boy, G. A. (2013) } \\
\text { [23] }\end{array}$ \\
\hline 7 & $\begin{array}{l}\text { An analysis on } \text { STEAM } \\
\text { education teaching and learning } \\
\text { program }\end{array}$ & $\begin{array}{l}\text { On technology } \\
\text { engineering areas }\end{array}$ & Ahn, J., (2013) [24] \\
\hline 8 & STEAM teaching practices & $\begin{array}{l}\text { Developing a conceptual } \\
\text { model }\end{array}$ & $\begin{array}{l}\text { Quigley, C. F. (2017) } \\
\text { [25] }\end{array}$ \\
\hline 9 & $\begin{array}{l}\text { From interdisciplinary to } \\
\text { transdisciplinary }\end{array}$ & $\begin{array}{l}\text { An arts-integrated approach } \\
\text { to STEAM education }\end{array}$ & Liao, C. (2016). [26] \\
\hline 10 & STEAM Education & Study on the current status & Park, H., (2016) [27] \\
\hline 11 & STEAM as social practice & $\begin{array}{l}\text { Cultivating creativity } \\
\text { transdisciplinary spaces }\end{array}$ & $\begin{array}{l}\text { Guyotte, K. W., } \\
(2014)[28]\end{array}$ \\
\hline 12 & $\begin{array}{l}\text { STEAM Education through Case } \\
\text { Studies }\end{array}$ & $\begin{array}{l}\text { Examination of the Practical } \\
\text { Model }\end{array}$ & $\begin{array}{l}\text { KIM, J. W. (2015) } \\
\text { [29] }\end{array}$ \\
\hline 13 & From STEM to STEAM & $\begin{array}{l}\text { Students' beliefs about the } \\
\text { use of their creativity }\end{array}$ & $\begin{array}{l}\text { Oner, A. T., (2016) } \\
\text { [30] }\end{array}$ \\
\hline
\end{tabular}

\subsection{Improving Competency through Employability Skills Enhancement Model :}

Competency means ability or capability to do things effectively and performance is the proof of competency. The objective of higher education is to impart competency to the learners and the 
presumption is that those who undergo higher education have acquired competency. But based on many studies, it is evident that a major portion of engineering graduates have lack of competency to be employed. This problem can be resolved by means of offering special training on employability skills enhancement during the engineering course by adopting such training in the college curriculum. Many research papers published on such industry oriented employability skills to be inculcated with the students to transfer them as employable graduates. A review on some of the papers on employability skills enhancement based education is given in Table 3.

Table 3 : Published papers related to Employability skills enhancement based education

\begin{tabular}{|c|c|c|c|}
\hline $\begin{array}{l}\text { S. } \\
\text { No. }\end{array}$ & ESEP Curriculum & Focus & Reference \\
\hline 1 & Career management skills & $\begin{array}{l}\text { Enhancing } \\
\text { employability }\end{array}$ & $\begin{array}{l}\text { Bridgstock, R. (2009). } \\
\text { [31] }\end{array}$ \\
\hline 2 & $\begin{array}{l}\text { Employability skills in higher } \\
\text { education }\end{array}$ & $\begin{array}{l}\text { Various methods in order to } \\
\text { promote employability skills in } \\
\text { HE }\end{array}$ & $\begin{array}{l}\text { Asonitou, S. (2015). } \\
\text { [32] }\end{array}$ \\
\hline 3 & A European study & $\begin{array}{l}\text { Graduate employability, 'soft } \\
\text { skills' versus 'hard' business } \\
\text { knowledge }\end{array}$ & $\begin{array}{l}\text { Andrews, J., (2008) } \\
{[33]}\end{array}$ \\
\hline 4 & $\begin{array}{l}\text { Engineering employability } \\
\text { skills required by employers }\end{array}$ & In Asian countries & $\begin{array}{l}\text { Zaharim, A., (2009) } \\
\text { [34] }\end{array}$ \\
\hline 5 & $\begin{array}{l}\text { Recognizing the } \\
\text { enhancement of graduate } \\
\text { attributes and employability }\end{array}$ & $\begin{array}{l}\text { Through part-time work while } \\
\text { at university }\end{array}$ & $\begin{array}{l}\text { Muldoon, R. (2009). } \\
\text { [35] }\end{array}$ \\
\hline 6 & $\begin{array}{l}\text { Methods and Approaches for } \\
\text { Employability Skill } \\
\text { Generation }\end{array}$ & $\begin{array}{lll}\text { In Higher } & \text { Educational } \\
\text { Institutions } & \end{array}$ & $\begin{array}{l}\text { Aithal, P. S., (2015). } \\
\text { [36] }\end{array}$ \\
\hline 7 & $\begin{array}{l}\text { Bridging the gap between } \\
\text { degree programme curricula } \\
\text { and employability }\end{array}$ & $\begin{array}{l}\text { Through implementation of } \\
\text { work-related learning }\end{array}$ & $\begin{array}{l}\text { Hills, J. M., (2003) } \\
\text { [37] }\end{array}$ \\
\hline 8 & $\begin{array}{l}\text { Defining and measuring } \\
\text { employability }\end{array}$ & Measurement ideas & $\begin{array}{l}\text { Harvey, L. (2001). } \\
{[38]}\end{array}$ \\
\hline
\end{tabular}

3. OBJECTIVES :

This paper is a conceptual suggestion based proposal to convert B.Tech. (Pass) course into B.Tech. (Honours) with the following objectives :

(1) To study emerging models in undergraduate engineering programmes and emerging technologies in the $21^{\text {st }}$ century to be incorporated in the curriculum of undergraduate engineering programmes.

(2) To propose employability and research oriented curriculum in engineering education based on emerging technologies.

(3) To suggest an innovative curriculum scheme based on STEAM and employability skill enhancement Program (ESEP) papers along with a focus on research in the improved model.

(4) To analyse such improved Honours degree in engineering by identifying its advantages, benefits, constraints, and disadvantages from students, institutions, and job offering industries point of view.

(5) To provide recommendations based on the analysis to make this model of B.Tech. (Honours) more effective in its objective of enhancing competency and employability of graduates to secure better employment.

\section{EMERGING MODELS IN UNDERGRADUATE ENGINEERING EDUCATION :}

\subsection{New Models in Engineering Education :}

Autonomy for higher education institutions supported many innovations in course identification, course design, course pedagogy, student services, examination, and evaluation systems. Engineering education, being a prominent field in higher education, became witness in such innovations. Many student centric models are offered in engineering education during last few years mostly by 
autonomous and private universities. Some of such successful models which attracted many students are as follows :

(1) Industry Integrated B.E./B.Tech. Programs :

These courses are designed to train students for specific industries. The curriculum of such courses is designed by involving experts from such industries along with academicians. Such courses will have more practical components in the form of industry specific projects and industry based internships.

(2) Super speciality B.E./B.Tech. Programs :

These courses are designed to train the students in emerging engineering and technology areas to full fill the requirements in future industries. These emerging areas usually falls under General purpose technologies which offers huge job opportunities in future days in many industries.

(3) Skill focussed B.E./B.Tech. Programs :

These courses focus on developing some specific skills along with the general requirements of engineering knowledge, skills, and experience. Usually, these courses have components which are taught by a specific set of professionals or consultants who have proprietary knowledge in that area.

(4) B.E./B.Tech. Programs with Multi-continent exposure :

In this model, students are exposed to different educational environment by taking them to three to four continent. The students get multi-cultural, multi-teaching- learning atmosphere, along with multcountry industry exposure. Student will study foreign language, and the attitude of other country people due to their immersion in different country environment. The social and technological scenarios will modify the critical and creative thinking abilities to contribute differently to their future organizations.

(5) Integrated Dual degree during B.E./B.Tech. Programs :

In this model, a student registers for two university degrees simultaneously either at the same institution or at different institutions of same university or some times of different universities. This model allows a student to study two degrees in different subject areas simultaneously so that the precious time resource can be utilized effectively. Such studies may be of two different undergraduate programmes as parallel programmes in different disciplines or two sequential programmes as undergraduate and postgraduate programmes in a single discipline.

(6) Research focussed B.E./B.Tech. Programs :

Undergraduate degree programmes in engineering can be made innovative and more intensive by integrating research components in one or more semesters so that along with conceptual and practical studies, students are compulsorily involved in research and publications along with the faculty members so that students are exposed to systematic innovative thinking and analysis.

\subsection{Emerging Technologies to be Incorporated in Engineering Education :}

The future education is mostly driven by technology and hence customizable. In this century, education sector, being a part of the service industry is also going to witness the fourth industrial revolution (IR 4.0) with the features of mass customization, personalization, and student centric approach. The technology based disruptive model of education is going to be a driving force of future education at both school and college levels. The engineering education also be accessed via following nine trends [x] which include (1) ubiquitous education model, (2) personalized learning model, (3) choice based pedagogy model, (4) project \& experimental based learning model, (5) field based learning through internship, (6) data interpretation skills, (7) competency based evaluation model, (8) teachers as facilitators \& guides during learning process, and (9) student-self designed curriculum model. These trends of education 4.0 can be realized using various emerging technologies under the umbrella of ICCT (Information communication and computation Technology) and nanotechnology. The various emerging technologies which have an impact on teaching - learning and various industrial applications [39-42] are :

(1) Artificial Intelligence : Artificial intelligence (AI) is an area of computer science which focuses on the creation of intelligent machines which can mimic the decisions of human beings. The primary objective of AI technology is to develop machines which can think and do things better than human beings. The main functions of artificial intelligence machines are to recognize the environment such as speech recognition, Learning, Planning, Problem solving, and hence decision making. Artificial intelligence machine mimics cognitive functions of human beings associated with other human minds, such as learning \& memorising and decision making for problem solving. ICCT has created a 
platform for AI to be introduced and developed for adding intelligent thinking components in electronic systems used in any industrial sectors. Artificial intelligence has its applications in almost all industries in the primary sectors, secondary sectors, tertiary sectors, and quaternary sector.

(2) Machine learning : Machine Learning is the learning in which machine can learn by its own without being explicitly programmed. It is an application of artificial intelligence that provides the system with the ability to automatically learn and improve from experience. Machine learning is based on the idea that we can build machines to process data and learn on their own, without our constant supervision.

(3) Robotics : Robotics technology deals with the study of design, construction, operation, and application of computerized robots and their control, sensory feedback, and information processing abilities. Robotics technologies are useful in developing machines that can replicate and substitute human actions.

(4) Internet of things : It is a network of various electronic, computing, and optical devices/objects including human beings connected virtually by means of internet or intranet for enabling them to send and receive data and information. These objects are provided with unique identifiers (UIDs) and are capable to transfer data and information over a network without requiring human-to-human or human-to-computer interaction by using IoT technology. Such a connection of physical things/objects through the Internet allows to access remote sensor data and to control the physical devices connected to it from a distance. The data captured from such sources, can create new synergistic services which will be superior to such services provided by an isolated embedded system. Internet-of-Things (IoT) is not in any new disruptive technology but is the pervasive deployment and innovation of ICCT.

(5) Autonomous vehicles : An autonomous vehicle can guide itself without human control. This kind of vehicle has become a concrete reality and may pave the way for future systems where computers take over the art of driving. An autonomous car is also known as a driverless car, robot car, self-driving car or autonomous vehicle. An autonomous vehicle is an application of artificial intelligence and machine learning in automobile engineering.

(6) Bio and nanotechnology : Bionanotechnology is a branch of nanotechnology which uses biological starting materials, utilises biological design or fabrication principles or is applied in medicine or biotechnology. For example, nanoparticles can serve as probes, sensors or vehicles for biomolecule delivery in cellular systems.

(7) 3-D printing : 3D printing is an ICCT application where various materials are joined or solidified using various processes under the control of the computer to create a three-dimensional object. In 3D printing, an object is created by laying down successive layers of material until the object is created. 3D printing can be divided into metal, fabrics, bio and a whole host of other industries with many applications in many industries worldwide. 3D printing is a variant of ICCT general purpose technology and has wide scope in various industrial automation and home automation processes. 3D printing technology is expected to revolutionise the material fabrication processes. 3D printing comprises of many other technologies along with ICCT. Some of the 3D printers make use of nanomaterials and nanocomposites for anything, anywhere manufacturing.

(8) Material science for energy Storage : Sustainable materials are the key requirement of many advanced energy technologies including solar cells, batteries, fuel cells, and catalysis. There is a large demand for cost-efficient methods for energy storage and conversion in the society and hence it has become imperative to accelerate the rate at which energy-related materials are developed. Material scientists are developing various materials which show improved properties like smart materials, superconductors, nanomaterials, polymers, etc.

(9) Quantum computing : High speed computers based on optical signal switching and optical signal processing are expected to breakthrough with their full potentials and capabilities using optical logic gates and flip-flops fabricated by nanocomposites are expected to breakthrough in this century. High speed computation and data storage using nanotechnology based optical/quantum computers are going to revolutionize the entire computer industry. Optical computation is joining both general purpose technologies of Nanotechnology and ICCT through the processes of design \& production as well as operation \& applications respectively. Various optical principles like photo-refraction, optical spatial solitons, and optical logic gates are under considerations for building all-optical computers. 
(10) Business Analytics : The emerging subfield of ICCT named big data and business analytics focus on handling huge amount of data continuously generated in any business or data capturing process and analyses it using various quantitative analytical techniques and mathematical models to study the pattern and descriptive information, predictive information, and prescriptive information for supporting the decision makers to take optimum decisions to the problems related to future aspects of the business. Predictive analytics in various functional areas like Marketing analytics, Retail Analytics (Customer Analytics/ Supply Chain Analytics), Pricing Analytics, Financial analytics, Social media analytics, sports analytics, and Healthcare analytics are finding importance in the business environment for effective decision making. Further Prescriptive Analytics for optimizing the decisions with multiple objectives/ portfolio analytics, optimizing complex decisions/ sales force analytics, and Retail Analytics etc are also have futuristic impact on effective business decisions.

(11) Cloud Computing : Cloud computing is one of the advances in computer technology and is uses information communication technology as well. Due to the ubiquity of cloud computing facility with flexibility in scaling it has become an important topic of research and provides the value for computing processes in the business. The cloud computing model also provides a most important application called Business Intelligence (BI) for effective decision making in business processes via the Internet. Cloud computing model provides its clients with both hardware as well as software to process the data and information online as a rental service. Cloud computing model has three variations as Software as a Service (SaaS), Infrastructure-as-a-Service (IaaS) and Platform-as-aService (PaaS) to provide ubiquitous computing service solutions to the business. The cloud computing solution used by any business will allow companies to reduce their investment cost, maintenance cost, and hence business cost without compromising to have access to BI solution which will give the business an edge on their competition.

(12) Blockchain Technology : Blockchain is basically a growing list of records containing data or information, called blocks, which are linked using a secured technique called cryptography. Every such block contains a cryptographic hash code of the previous block, a timestamp, and transaction data. By design, a blockchain is resistant to modification of the data. Blockchain gives the history of currency transaction and hence its spending pattern. Blockchain technology is widely used by cryptocurrency transactions. The discovery of the blockchain technology for bitcoin made it the first digital currency to solve the double-spending problems without the need of a trusted authority. Blockchain technology has potential applications in digital currency technology and secured transactions.

(13) Online education technology : Online educational technology supports learning from distance so that a person can earn educational credentials and improve his performance by creating, using and managing appropriate technological processes and resources using internet and multimedia technologies. Online educational technology is the use of both physical hardware and educational theoretic along with wireless systems and internet. This technology has huge amount of applications in many kinds of services in almost all industry sectors for training and development.

(14) Virtual \& Augmented Reality : Virtual reality is an artificial environment that is created with the help of computer-based software and presented to the user in such a way that the user suspends belief and accepts it as a real environment. On a computer, virtual reality is primarily experienced through two of the five senses: sight and sound. Currently, the virtual reality is mainly developed and used in simulated training and education as well as the simulated game environment. But it may further find its applications in many other areas including business as augmented reality and may enter the group of general purpose technology.

These emerging technologies have many applications in engineering industries. Having knowledge and learning such technologies is essential for undergraduates during their studies so that such exposure

\section{EMPLOYABILITY \& RESEARCH ORIENTED CURRICULUM BASED ON EMERGING TECHNOLOGIES :}

Engineering graduates are expected to have certain minimum knowledge, skills, and experience as their graduate attributes to identify problems, design solutions, and develop processes and products with new innovative features in industries. Creativity, design thinking, problem solving, self- 
motivation, positive attitude towards professional challenges, working culture, team work and leadership qualities are essential traits to be successful in getting good job and further promotions. Engineering colleges should focus on planning and implementing such education model which can offer essential employability skills to their students. Some of major employability skills for engineering graduates are in table 4 along with their description and method of acquiring.

Table 4: Major Employability skills required for Engineering graduates

\begin{tabular}{|c|c|c|c|}
\hline $\begin{array}{l}\text { S. } \\
\text { No. }\end{array}$ & Employability skills & Description & Method of gathering \\
\hline 1 & $\begin{array}{l}\text { Effective } \\
\text { Communication skills }\end{array}$ & $\begin{array}{l}\text { Communication of information in } \\
\text { understandable manner and in right } \\
\text { time }\end{array}$ & Training \\
\hline 2 & Team work skills & $\begin{array}{l}\text { To increase the performance of the } \\
\text { team }\end{array}$ & $\begin{array}{l}\text { Target based group } \\
\text { projects }\end{array}$ \\
\hline 3 & Problem solving skills & $\begin{array}{l}\text { Use a combination of intuition and } \\
\text { logic to come up with right } \\
\text { solutions at right time }\end{array}$ & $\begin{array}{l}\text { Experimental learning } \\
\begin{array}{ll}\text { based laboratory } \\
\text { courses }\end{array}\end{array}$ \\
\hline 4 & $\begin{array}{l}\text { Data interpretation \& } \\
\text { Numerical competency }\end{array}$ & $\begin{array}{l}\text { To measure an individual's ability } \\
\text { to interpret and manipulate data, } \\
\text { which is required in most industry } \\
\text { roles }\end{array}$ & Skill labs \\
\hline 5 & Leadership skills & $\begin{array}{l}\text { How to analyze, how to synthesize, } \\
\text { and evaluate situations to make } \\
\text { sound decisions }\end{array}$ & Training \\
\hline 6 & Technology skills & Technology awareness & Technology adoption \\
\hline 7 & $\begin{array}{l}\text { Self-awareness \& } \\
\text { Competency in specific } \\
\text { engineering discipline }\end{array}$ & $\begin{array}{l}\text { Re-defining the goal \& SWOC } \\
\text { analysis }\end{array}$ & Competitions \\
\hline 8 & $\begin{array}{lr}\begin{array}{l}\text { Attitude } \\
\text { responsibility } \\
\text { work }\end{array} & \text { towards } \\
\end{array}$ & $\begin{array}{l}\text { Accountability in overall } \\
\text { performance }\end{array}$ & $\begin{array}{lll}\begin{array}{l}\text { Workshops } \\
\text { works }\end{array} & \& & \text { Field } \\
\end{array}$ \\
\hline 9 & $\begin{array}{l}\text { Innovative \& creative } \\
\text { thinking }\end{array}$ & $\begin{array}{l}\text { Research based new knowledge } \\
\text { creation }\end{array}$ & IPR \\
\hline 10 & Design thinking & Product and Design \& simulation & Self designed courses \\
\hline
\end{tabular}

\section{B.TECH. (HONOURS) MODEL WITH STEAM \& EMPLOYABILITY SKILLS FOCUS :}

Based on focus group analysis, we have gather ideas and concepts to improve engineering curriculum with above requirements of new knowledge, new skills, new experience through hard and dedicated learning model which is based on STEAM, Employability enhancement features, creating intellectual properties and industry oriented internship for the $21^{\text {st }}$ century education Industry 4.0 version. The findings are postulated as follows :

(1) Semesters with increased subjects \& Credits (from 6 to 9 subjects \& from 20 Credits to 25 Credits).

(2) Redesigning the Subjects in each Semester as per STEM/STEAM model wherever possible with emerging technologies.

(3) Increasing Experimental/lab based learning (EL) part in each semester so that equal importance is given to theory and practicals.

(4) Introducing employability skills enhancement papers (ESEP) in each semester from Industry Experts.

(5) Focussing on IPR awareness and Patent analysis in every student's specialized area. 
(6) Mini projects introduced in every semester for team work experience, Main project in specialized area through six months industry internship, and Compulsory IP generation through Copyright/Patenting/International Journal Publication of the internship based project.

The above postulates are identified as integrated student development framework in engineering based on STEAM-Employability Model with a focus on experimental learning and IPR generation. The model is also represented in the form of a block diagram as shown in figure 1.

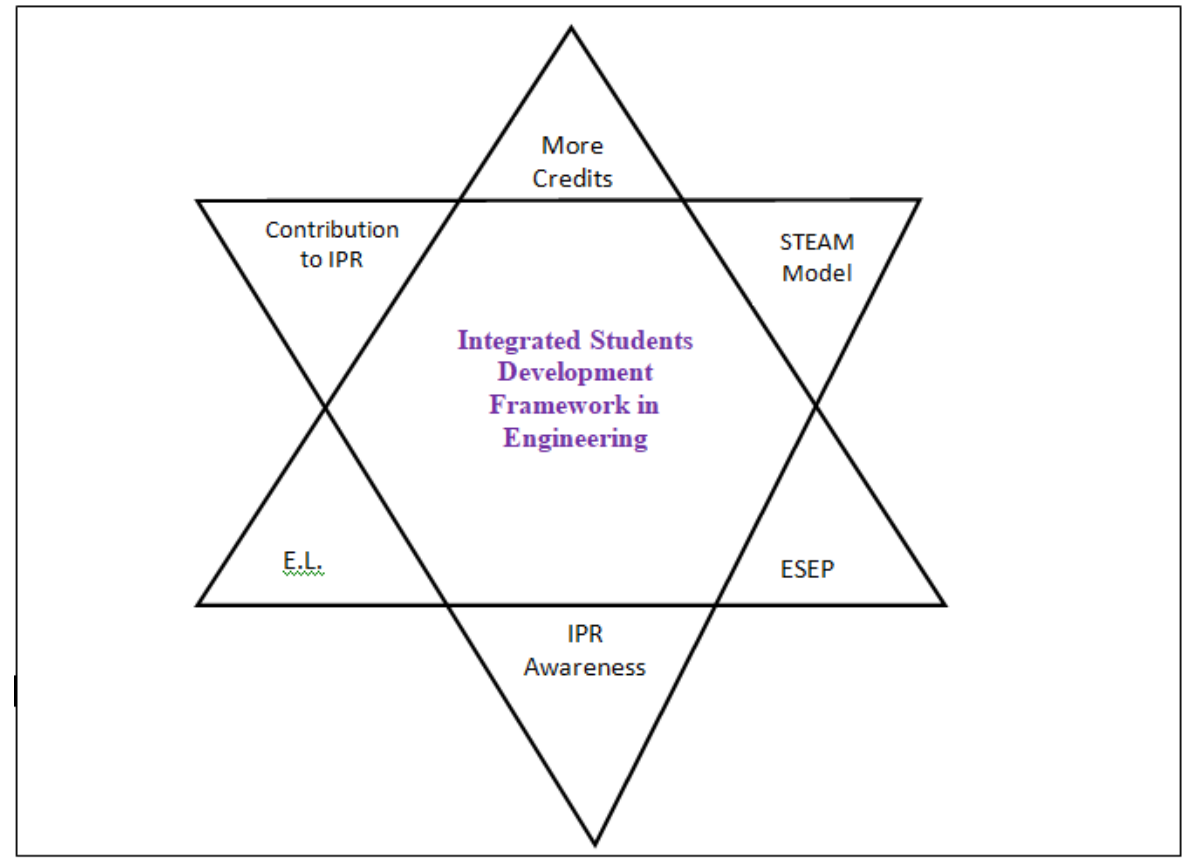

Fig. 1 : Integrated Student development Framework for effective engineering education

The ideas and concepts to improving engineering curriculum with above requirements of new knowledge, new skills, new experience through hard and dedicated learning model which is based on STEAM (Science, technology, Engineering, Arts \& Design, and Mathematics), Employability skills enhancement program (ESEP) features, creating intellectual properties, and industry oriented internship.

\section{COMPARISON OF B.TECH (HONOURS) MODEL WITH B.TECH. (PASS) MODEL :}

The newly proposed integrated student development model (ISDM) is compared with the traditional undergraduate engineering model of many universities in India and the comparative features are listed in table 5.

Table 5 : Comparison of the features of B.Tech (Hons) and B.Tech (Pass) model

\begin{tabular}{|l|l|l|}
\hline S. No. & B.Tech. (Pass) & B.Tech. (Hons) \\
\hline 1 & $\begin{array}{l}\text { Less number of papers per } \\
\text { semester (6 to 7) }\end{array}$ & More number of papers per semester (8 to 10) \\
\hline 2 & About 18 to 20 credits per semester & 25 credits per semester \\
\hline 3 & SEM Model & STEAM Model \\
\hline 4 & Less lab based experiments papers & Equal number of theory and laboratory papers \\
\hline 5 & $\begin{array}{l}\text { No focus on Employability Skill } \\
\text { Enhancement in each semester }\end{array}$ & $\begin{array}{l}\text { Two Employability Skill Enhancement Papers } \\
\text { (ESEP) in each semester }\end{array}$ \\
\hline 6 & $\begin{array}{l}\text { University centric Examination } \\
\text { system }\end{array}$ & Student centric Examination system \\
\hline 7 & No projects in every semesters & Teamwork based projects in every semesters \\
\hline 8 & No IPR training to motivate & Compulsory IPR training in fourth semester to create \\
\hline
\end{tabular}




\begin{tabular}{|l|l|l|}
\hline & $\begin{array}{l}\text { students for new knowledge } \\
\text { creation }\end{array}$ & awareness about patent \& copyright \\
\hline 9 & $\begin{array}{l}\text { No papers and training on patent } \\
\text { analysis }\end{array}$ & $\begin{array}{l}\text { Training and involvement of students on existing } \\
\text { patents analysis in their special subjects. }\end{array}$ \\
\hline 10 & $\begin{array}{l}\text { No compulsory project work based } \\
\text { on full semester internship }\end{array}$ & $\begin{array}{l}\text { Compulsory project work based on full semester } \\
\text { internship and compulsory patent application } \\
\text { filing/journal publication }\end{array}$ \\
\hline
\end{tabular}

\section{ABCD ANALYSIS OF STEM \& ESEF B.TECH. (HONS) MODEL :}

Out of many analysis frameworks developed to analyse a system, concept, ideas, models, or strategies, ABCD analysis framework is an effective and simple framework which analyse the usage of the system/model, factors affecting the system/model, and deep insight into the system/model through identifying critical constitutional elements (elemental analysis) [43-46]. The variation in $A B C D$ analysis called ABCD listing is a qualitative discussion method. ABCD listing consists of a listing of advantages, benefits, constraints, and disadvantages of the usage of the system/model [4763]. Here, we have listed the advantages, benefits, constraints, and disadvantages of Integrated student development model leading to B.Tech. (Hons) in the engineering education system are listed below :

\subsection{Advantages :}

(1) Students are exposed to more advanced and emerging topics with enhanced subjects and credits in each semester.

(2) The subjects are identified in initial semesters using STEAM model. This will enhance their comprehensive and specific knowledge on basics and supportive subjects. The inclusion of arts and design topics in the curriculum supports the students to think creatively for effective design and implementations of engineering solutions in the industry.

(3) Increased laboratory based subjects in each semester enhance the flavour of experimental learning so that students involve in developing practical solutions to the problems related to their studies and gather hands-on experience.

(4) Additional employability skills from industry leaders enhances the competency of the students where students are trained to improve communication skills, problem solving skills, data analysis skills, reasoning skills, teamwork skills, numerical competency, design thinking, etc. This will also improve their confidence in facing real-life challenges.

(5) One of the important features of this integrated student development model is setting a target to generate IPR by a student before completing the course either in the form of patent or copyright of their projects by creating awareness on IPR, Patent analysis on their specialization subjects during different semesters so that students will eventually develop ideas on new process or new products.

(6) The training provided on the importance and procedure of developing and registering IPR during the course will educate and motivate every student to come out with a patent/copyright or a journal publication which is an essential requirement of the course completion certificate so that whenever there is a compulsion, students will work hard and reach their goal which can effectively differentiate them from other University students.

8.2 Benefits :

(1) Increased number of papers per semester : Enhanced knowledge in many subjects

(2) Increased credits per semester : More credits and more marks

(3) STEAM Model : Enhanced creativity \& design thinking

(4) Increased laboratory papers : learning through experiments

(5) ESEP papers in every semester : Enhanced employability skills and better job

(6) Teamwork based projects in every semesters : Leadership, communication and team work skills

(7) Compulsory IPR training : Awareness about IPR

(8) Patents analysis \& publication : Idea on patent development \& drafting

(9) Compulsory patent application filing/journal publication based on internship project : IPR/Scholarly publication in student name.

\subsection{Constraints :}


(1) More resources like teaching faculty, Experimental laboratory facilities are required.

(2) Additional subjects on Arts \& design have to be taught.

(3) Industry experts are required for ESEP.

(4) Students have to spend more time in training activities.

(5) Training on IPR and patent analysis need experts.

(6) Continuous motivation and support to the students for developing patentable/ scholarly article based on project internship.

8.4 Disadvantages :

(1) Costly for the institution and hence for the students

(2) More time consuming for stakeholders

(3) Only interested and challenge seeking students will opt for the course so that there may be less admission to the course.

(4) Developing the system for implementation takes time.

\section{CONCLUSION :}

An innovative, effective, efficient new model in engineering education is proposed. This Integrated student development model based on STEAM, ESEP \& IPR features enhances the weightage of conventional B.Tech. (pass) course and elevate it to highly employable based on enhanced competency in concerned engineering subjects called as B.Tech. (Hons). It is predicted that B.Tech. (Hons) graduates have better capability to work and solve problems in the industry due to their enhanced knowledge, skills, experience, and confidence. Such innovations in existing higher education courses are essential to ensure that the graduates studied in such courses are useful for society to contribute to their specialized fields.

\section{REFERENCES :}

[1] Aithal P. S., \& Suresh Kumar P. M. (2018). Approaches to Confidence Building as a Primary Objective in Postgraduate Degree Programmes. International Journal of Applied Engineering and Management Letters (IJAEML), 2(1), 64-71. DOI: http://dx.doi.org/10.5281/zenodo.1205185.

[2] Aithal P. S., \& Suresh Kumar P. M. (2019). Evolving a Competency Based Grading System for Higher Education. International Journal of Applied Engineering and Management Letters (IJAEML), 3(1), 60 .

[3] Felder, R. M., Woods, D. R., Stice, J. E., \& Rugarcia, A. (2000). The future of engineering education II. Teaching methods that work. Chemical Engineering Education, 34(1), 26-39.

[4] Parashar, A. K., \& Parashar, R. (2012). Innovations and curriculum development for engineering education and research in India. Procedia-Social and Behavioral Sciences, 56, 685-690.

[5] Kırkgöz, Y. (2009). The challenge of developing and maintaining curriculum innovation at higher education. Procedia-Social and Behavioral Sciences, 1(1), 73-78.

[6] Ostler, E. (2012). 21st century STEM education: a tactical model for long-range success. International Journal of Applied Science and Technology, 2(1).

[7] Engberg, M., \& Wolniak, G. C. (2013). College student pathways to the STEM disciplines. Teachers College Record, 115(1).

[8] Beach, A. L., Henderson, C., \& Finkelstein, N. (2012). Facilitating change in undergraduate STEM education. Change: The Magazine of Higher Learning, 44(6), 52-59.

[9] Porter, A. L., Roessner, J. D., Oliver, S., \& Johnson, D. (2006). A systems model of innovation processes in university STEM education. Journal of Engineering Education, 95(1), 13-24.

[10] Roehrig, G. H., Johnson, C. C., Moore, T. J., \& Bryan, L. A. (2015). Integrated STEM education. In STEM road map (pp. 23-37). Routledge. 
[11] Fan, S. C., \& Yu, K. C. (2017). How an integrative STEM curriculum can benefit students in engineering design practices. International Journal of Technology and Design Education, 27(1), 107129.

[12] Connor, A., Karmokar, S., \& Whittington, C. (2015). From STEM to STEAM: Strategies for enhancing engineering \& technology education. International Journal of Engineering Pedagogy, 5(2), 37-47.

[13] Wells, J. G. (2008, November). STEM education: The potential of technology education. In 95th Mississippi Valley Technology Teacher Education Conference, St. Louis, MO (Vol. 41).

[14] Ritz, J. M., \& Fan, S. C. (2015). STEM and technology education: International state-of-theart. International Journal of Technology and Design Education, 25(4), 429-451.

[15] Avery, Z. K., \& Reeve, E. M. (2013). Developing effective STEM professional development programs. Journal of Technology Education, 25(1), 55-69.

[16] Watson, A. D., \& Watson, G. H. (2013). Transitioning STEM to STEAM: Reformation of engineering education. Journal for Quality \& Participation, 36(3), 1-4.

[17] Madden, M. E., Baxter, M., Beauchamp, H., Bouchard, K., Habermas, D., Huff, M., ... \& Plague, G. (2013). Rethinking STEM education: An interdisciplinary STEAM curriculum. Procedia Computer Science, 20, 541-546.

[18] Kim, Sung-Won, et al. "Development of a theoretical model for STEAM education." Journal of the Korean Association for Science Education 32.2 (2012): 388-401.

[19] Kim, Y., \& Park, N. (2012). Development and application of STEAM teaching model based on the Rube Goldberg's invention. In Computer science and its applications (pp. 693-698). Springer, Dordrecht.

[20] Kim, J. A., Kim, B. S., Lee, J. H., \& Kim, J. H. (2011). A study of teaching-learning methods for the it-based STEAM education model with regards to developing people of interdisciplinary abilities. Journal of Fisheries and Marine Sciences Education, 23(3), 445-460.

[21] Madden, M. E., Baxter, M., Beauchamp, H., Bouchard, K., Habermas, D., Huff, M., ... \& Plague, G. (2013). Rethinking STEM education: An interdisciplinary STEAM curriculum. Procedia Computer Science, 20, 541-546.

[22] Watson, A. D., \& Watson, G. H. (2013). Transitioning STEM to STEAM: Reformation of engineering education. Journal for Quality \& Participation, 36(3), 1-4.

[23] Boy, G. A. (2013, August). From STEM to STEAM: toward a human-centred education, creativity \& learning thinking. In Proceedings of the 31st European conference on cognitive ergonomics (p. 3). ACM.

[24] Ahn, J., \& Kwon, N. (2013). An analysis on STEAM education teaching and learning program on technology and engineering. Journal of the Korean Association for Science Education, 33(4), 708717.

[25] Quigley, C. F., Herro, D., \& Jamil, F. M. (2017). Developing a conceptual model of STEAM teaching practices. School Science and Mathematics, 117(1-2), 1-12.

[26] Liao, C. (2016). From interdisciplinary to transdisciplinary: An arts-integrated approach to STEAM education. Art Education, 69(6), 44-49.

[27] Park, H., Byun, S. Y., Sim, J., Baek, Y. S., \& Jeong, J. S. (2016). A study on the current status of STEAM Education. Journal of the Korean Association for Science Education, 36(4), 669-679.

[28] Guyotte, K. W., Sochacka, N. W., Costantino, T. E., Walther, J., \& Kellam, N. N. (2014). STEAM as social practice: Cultivating creativity in transdisciplinary spaces. Art Education, 67(6), 12-19. 
[29] KIM, J. W., \& WON, H. H. (2015). Examination of the Practical Model for STEAM Education through Case Studies. Journal of Fisheries and Marine Sciences Education, 27(6), 1676-1684.

[30] Oner, A. T., Nite, S. B., Capraro, R. M., \& Capraro, M. M. (2016). From STEM to STEAM: Students' beliefs about the use of their creativity. The STEAM Journal, 2(2), 6.

[31] Bridgstock, R. (2009). The graduate attributes we've overlooked: Enhancing graduate employability through career management skills. Higher Education Research \& Development, 28(1), 31-44.

[32] Asonitou, S. (2015). Employability skills in higher education and the case of Greece. ProcediaSocial and Behavioral Sciences, 175, 283-290.

[33] Andrews, J., \& Higson, H. (2008). Graduate employability,'soft skills' versus 'hard'business knowledge: A European study. Higher education in Europe, 33(4), 411-422.

[34] Zaharim, A., Yusoff, Y., Omar, M. Z., Mohamed, A., \& Muhamad, N. (2009, July). Engineering employability skills required by employers in Asia. In Proceedings of the 6th WSEAS international conference on Engineering education (pp. 195-201).

[35] Muldoon, R. (2009). Recognizing the enhancement of graduate attributes and employability through part-time work while at university. Active Learning in Higher Education, 10(3), 237-252.

[36] Aithal, P. S., Suresh Kumar, P.M., and Kumari, Pavithra, (2015). Methods and Approaches for Employability Skill Generation in Higher Educational Institutions. International Journal of Management, IT and Engineering, 5(7), 390-410.

[37] Hills, J. M., Robertson, G., Walker, R., Adey, M. A., \& Nixon, I. (2003). Bridging the gap between degree programme curricula and employability through implementation of work-related learning. Teaching in Higher Education, 8(2), 211-231.

[38] Harvey, L. (2001). Defining and measuring employability. Quality in higher education, 7(2), 97109.

[39] Anealka Aziz Hussin (2018). Education 4.0 Made Simple: Ideas For Teaching. International Journal of Education \& Literacy Studies, 6(3), 92-98. DOI : http://dx.doi.org/10.7575/aiac.ijels.v.6n.3p.92.

[40] Madhushree L. M, Revathi Radhakrishnan, P. S. Aithal (Jan 2019). A Review on Impact of Information Communication \& Computation Technology (ICCT) on Selected Primary, Secondary, and Tertiary Industrial Sectors. Saudi Journal of Business and Management Studies, 4(1), 106-127. ISSN 2415-6663, Scholars Middle East Publishers, Dubai, United Arab Emirates. DOI: http://doi.org/10.21276/sjbms.2019.4.1.14.

[41] Aithal, P. S. and Shubhrajyotsna Aithal. (2018). Study of various General-Purpose Technologies and their contribution towards developing Sustainable Society, International Journal of Management, Technology, and Social Sciences (IJMTS), 3(2), 16-33. ISSN : 2581-6012, DOI : http://dx.doi.org/10.5281/Zenodo.1409476.

[42] Aithal, P. S. (2018). Emerging Trends in ICCT as Universal Technology for Survival, Sustainability, Differentiation, Monopoly and Development. Conference Proceedings on Advances in Information Technology, Management, Social Sciences and Education, pp. 129- 139. December 2018, ISBN No.: 978-81-938040-8-7.

[43] Aithal, P. S., V.T. Shailashree, P. M. Suresh Kumar (2015). A New ABCD Technique to Analyze Business Models \& Concepts.International Journal of Management, IT and Engineering (IJMIE), 5(4), 409 - 423. DOI : http://doi.org/10.5281/zenodo.61652,

[44] Aithal, P. S., Shailashree V. T. \& Suresh Kumar P.M. (2016). Factors \& Elemental Analysis of Six Thinking Hats Technique using ABCD Framework. International Journal of Advanced Trends in Engineering and Technology (IJATET), 1(1), 85-95. DOI: http://doi.org/10.5281/zenodo.240259. 
[45] Aithal, P. S. (2017). Factor Analysis based on ABCD Framework on Recently Announced New Research Indices. International Journal of Management, Technology, and Social Sciences (IJMTS), 1(1), 82-94. DOI: http://dx.doi.org/10.5281/zenodo.584105.

[46] Aithal, P. S., (2016). Study on ABCD Analysis Technique for Business Models, business strategies, Operating Concepts \& Business Systems, International Journal in Management and Social Science, 4(1), 98-115. DOI : http://doi.org/10.5281/zenodo.161137.

[47] Varun Shenoy, \& Aithal P. S., (2016). ABCD Analysis of On-line Campus Placement Model. IRA-International Journal of Management \& Social Sciences, 5(2), 227-244. DOI: http://dx.doi.org/10.21013/jmss.v5.n2.p3.

[48] Aithal, P. S. \& Suresh Kumar, P. M. (2016). CCE Approach through ABCD Analysis of 'Theory $A^{\prime}$ on Organizational Performance. International Journal of Current Research and Modern Education (IJCRME), 1(2),169-185. DOI: http://dx.doi.org/10.5281/zenodo.164704.

[49] Aithal, P. S.,Shailashree V. T\& Suresh Kumar P. M., (2016). Analysis of ABC Model of Annual Research Productivity using ABCD Framework. International Journal of Current Research and Modern Education (IJCRME), 1(1), 846-858. DOI :http://doi.org/10.5281/zenodo.62022.

[50] Shubhrajyotsna Aithal \& Aithal P. S., (2016). ABCD analysis of Dye doped Polymers for Photonic Applications. IRA-International Journal of Applied Sciences, 4(3), 358-378. DOI : http://doi.org/10.5281/zenodo.155103. DOI : http://dx.doi.org/10.21013/jas.v4.n3.p1.

[51] Aithal, P. S., Shailashree, V. T. \& Suresh Kumar, P.M. (2016). The Study of New National Institutional Ranking System using ABCD Framework. International Journal of Current Research and Modern Education (IJCRME), 1(1), 389 - 402. DOI : http://doi.org/10.5281/zenodo.161077.

[52] Aithal, P. S., Shailashree, V.T.\& P.M. Suresh Kumar, Application of ABCD Analysis Framework on Private University System in India. International Journal of Management Sciences and Business Research (IJMSBR), 5(4), 159-170. DOI : http://doi.org/10.5281/zenodo.161111.

[53] Aithal, P. S., Shailashree, V. T. \& Suresh Kumar, P. M. (2016). Analysis of NAAC Accreditation System using ABCD framework. International Journal of Management, IT and Engineering (IJMIE), 6(1), 30-44. DOI : http://doi.org/10.5281/zenodo.154272.

[54] Aithal, P. S., Shailashree, V. T. \& Suresh Kumar, P. M. (2016). ABCD analysis of Stage Model in Higher Education. International Journal of Management, IT and Engineering (IJMIE), 6(1), 1124. DOI :http://doi.org/10.5281/zenodo.154233.

[55] Varun Shenoy \& Aithal, P. S. (2017). Quantitative ABCD Analysis of IEDRA Model of Placement Determination. International Journal of Case Studies in Business, IT and Education (IJCSBE), 1(2), 103-113. DOI: http://dx.doi.org/10.5281/zenodo.1133691.

[56] Architha Aithal, and Aithal, P. S. (2017). ABCD Analysis of Task Shifting - An optimum Alternative Solution to Professional Healthcare Personnel Shortage. International Journal of Health Sciences and Pharmacy (IJHSP), 1(2), 36-51. DOI: http://dx.doi.org/10.5281/zenodo.1038975.

[57] Aithal, P. S. (2017). ABCD Analysis as Research Methodology in Company Case Studies. International Journal of Management, Technology, and Social Sciences (IJMTS), 2(2), 40-54. DOI: http://dx.doi.org/10.5281/zenodo.891621.

[58] Aithal, P. S. (2016). Student Centric Curriculum Design and Implementation - Challenges \& Opportunities in Business Management \& IT Education. IRA International Journal of Education and Multidisciplinary Studies, 4(3), 423-437. DOI : http://dx.doi.org/10.21013/jems.v4.n3.p9.

[59] Shubrajyotsna Aithal \& Aithal, P. S., (2016). Student Centric Learning Through Planned Hardwork - An Innovative Model. International Journal of Scientific Research and Modern Education (IJSRME),1(1), 886-898. DOI: http://doi.org/10.5281/zenodo.61830. 
[60] Aithal, P. S., P. M. Suresh Kumar and Deekshitha, (2015). Societal Expectation and Institutional Accountability in Higher Education. International Journal of Management, IT and Engineering (IJMIE), 5(7), 361-373. DOI : http://doi.org/10.5281/zenodo.267021.

[61] Aithal, P. S., Suresh Kumar, P. M., and Pavithra Kumari, (2015). Methods and Approaches for Employability Skill Generation in Higher Educational Institutions. International Journal of Management, IT and Engineering (IJMIE), 5(7), 390-410. DOI: http://doi.org/10.5281/zenodo.267044.

[62] Aithal, P. S.,Shailashree V. T., \& P.M. Suresh Kumar, (2015) Application of ABCD Analysis Model for Black Ocean Strategy. International Journal of Applied Research (IJAR), 1(10), 331 - 337, DOI : http://doi.org/10.5281/zenodo.163424.

[63] Aithal, P. S., and P. M. Suresh Kumar, (2015). Applying SWOC Analysis to an Institution of Higher Education.International Journal of Management, IT and Engineering (IJMIE), 5(7), 231-247. DOI : http://doi.org/10.5281/zenodo.163425. 